\title{
EXPATRIATION OF ATHLETES AND THE THEORY OF INTERCULTURAL ADJUSTMENT
}

\author{
Ivan Wallan Tertuliano ${ }^{1}$ \\ Adventist University, São Paulo, Brazil \\ Bruna Alves Santana ${ }^{2}$ \\ Adventist University, São Paulo, Brazil \\ Vivian de Oliveira ${ }^{3}$ \\ University Center IESB, Brasilia, Brazil
}

\begin{abstract}
Cultural shock may be one of the greatest difficulties encountered by athletes and employees who choose to live and work in other countries. Therefore, the objective of this essay was to conceptualize the theory of intercultural adjustment and to point out proposals for the use of theory in the process of sports expatriation. For this, it was based on the methodological design of a qualitative research on the perspective of documentary analysis. As main reflections of this essay, the lack of an adequate cultural adjustment process for athletes and employees who are subject to living in another country is emphasized, in addition to the importance of the family in this process. Therefore, it also highlights the relevance that expatriates are submitted to a preparation process, either by psychological, social, economic and cultural bias, so that changes are faced in the best possible way, highlighting the importance of Intercultural Psychology.

Keywords: Intercultural adjustment, Expatriation, Migration, Intercultural Psychology
\end{abstract}

\section{INTRODUCTION}

Tylor (1920) defined culture as the set of beliefs, knowledge, art, morals, rules and laws, customs and all habits created by individuals of a society. With a globalized and increasingly connected world, thanks to the internet, cultural abysses seem to diminish, but the particularities of each society can still be a challenge for the subject who experiences living in an environment different from the one he knows.

In the case of this challenge, expatriation can be cited. Expatriation can be defined as moving people to countries that they do not have citizenship, that is, it is the act of changing countries, state and city in order to be able to continue life with regard to studies and work, for example (Tertuliano, Oliveira, Pavlović, \& Machado, 2018; Tertuliano, 2018; Tertuliano, Oliveira, \& Santana, 2019). In this way, Andreff (2010) corroborates the definition exposed by pointing out that people leave a country, state or city in search of new opportunities, jobs, cultures, etc. For athletes, often act outside of their countries of origin is one of the goals for

\footnotetext{
${ }^{1}$ Corresponding author. ivanwallan@gmail.com

2 brunnasantna@gmail.com

3 vivian_oliveira58@hotmail.com
} 
their careers, a dream, but not so this ceases to be a complicated process and full of difficulties (Tertuliano, Oliveira, Pavlović, \& Machado, 2018; Tertuliano, Machado, Deustch, Montiel, \& Bartholomeu, 2018; Tertuliano, Montiel, Deutsch, \& Machado, 2019; Tertuliano, Oliveira, \& Santana, 2019).

All expatriations and repatriations, in the sporting context or outside it, fall on the obstacles of social and cultural adjustment of the expatriate, being important the investigation about this phenomenon (González \& Oliveira, 2011), called intercultural adjustment. Intercultural adjustment is related to the facilities and difficulties found by those professionals who venture to live in a country other than its origin, relating to the process of adaptation to this new reality (Lee \& Vorst, 2010; Sousa, 2014). For this adjustment to be successful in the sports environment there are factors that must be considered, which will be presented in this text.

Thus, the aim of this essay was to conceptualize the theory of intercultural adjustment and to point out proposals for the use of theory in the process of sports expatriation. In order to present and propose academic-professional postures, this essay aimed to bring a direction, in which classical and contemporary studies were used to weave on the theme providing a greater radius of reflection. Thus, it was based on the methodological design of a qualitative research on the perspective of documentary analysis (Marconi \& Lakatos, 2017).

\section{EXPATRIATION - INTERCULTURAL ADJUSTMENT}

The literature suggests different definitions of cultural adjustment (Lee \& Vorst, 2010; Sousa, 2014). For Lee \& Vorst (2010) it is the ease or difficulty that the person finds in personal and professional relationships in the other country. Sousa (2014) defines intercultural adjustment as a process of adaptation to a new life and work in another culture, involving daily routines, housing, food, health, cost of living and interaction with people from the new country.

Intercultural adjustment can be influenced by the prior experience of expatriation, individual characteristics of the expatriate, level of cultural difference of the country of origin and the country of destiny and adjustment of the family (Black et al., 1991). Black et al. (1991) propose three dimensions for intercultural adjustment: adaptation to work, general adaptation and adaptation regarding interaction. The adaptation to the work corresponds to the degree to which the expatriate adjusts to his role in the company, that is, the necessary adjustments to adapt to work patterns, leadership and professional relationships in the company, abroad. 
The general adaptation concerns the degree of adjustment, from the expatriate, the conditions of the welcoming country, such as temperature, food, transportation, shopping, fun and life in general. Finally, the adaptation regarding interaction corresponds to psychological comfort related to the relationship with people beyond the work environment, that is, how is the communication between expatriate and people of the new country and how people welcome it.

Tucker, Bonial, \& Lahti (2004) propose six factors for intercultural adjustment: (1) Acceptance of foreign culture - refers to the expatriate's acceptance of the culture of the new country, respecting local customs and traditions; (2) Knowledge of the country and culture - it is worth knowing the host country, its history, but also the current reality of it; (3) Intercultural adjustment of the way of life - adaptation of the way of life, managing, on the one hand, to continue to develop in the host country the activities he likes most, but also, on the other hand, to practice activities characteristic of that country; (4) Interaction with natives - interaction with the natives, both at work and in leisure time; (5) Communication - learning of local language, including understanding non-verbal communication; (6) Affection/Emotion - concerns the feeling of well-being and empathy towards the host country population.

When expatriates know a new culture, they face new values and behaviors, and may feel a sense of confusion and nervousness, the result of new cultural and social patterns. This reaction is called cultural shock (Pereira, Pimentel, \& Kato, 2005). Thus, it is necessary to adapt to the new culture and the new way of living (Black et al., 1991).

The literature points to the direction of cultural shock, as magnitude, to be related to cultural differences. Thus, the greater the cultural differences, the greater the cultural shock (Black et al., 1991; Martins, 2011; Pereira et al., 2005).

Black et al. (1991) suggest some characteristic manifestations of cultural shock: (a) Feeling of anxiety, confusion, tension, frustration and impatience; (b) Sense of loss of dominance of a situation; (c) Insomnia, stomach pains and headaches; (d) Fatigue, excessive concern with hygiene and the use of drugs and alcohol; (e) Feeling of loss and deprivation.

A relatively recent area, which appears around 1970, but with characteristics that can give the necessary support in the process of intercultural adjustment is intercultural psychology. Intercultural Psychology is concerned with understanding individuals from different cultures through the use of measurement methods that are equivalent to the cultures considered (Angelini, 2007). Within the skills that intercultural psychology develops with the process of intercultural adjustment, we have, as an example, to develop creativity and intelligence in the face of 
unexpected situations, adapt to different contexts in a way emotional, cognitive and social, among others (Sebben, 2009).

For a more balanced intercultural adjustment, it is necessary to adapt to a new context, which refers to the concept of cultural intelligence: ability to solve problems and adapt to different situations (Lee \& Sukoco, 2010). For Earley \& Ang (2003) cultural intelligence is a multifactorial construct, composed of 4 aspects: (1) Cognitive, which relate to the knowledge of different cultures, in relation to norms, cultural and practical conventions; (2) Metacognitive, involving mental processes of capturing and understanding the new cultural environment; (3) Motivational, who refer to the subject's desire to interact with the people of the new place and adapt to the new place; (4) Behavioral, that involves the ability to exhibit adaptive behaviors such as accent, tone of voice, verbal expressions, etc. (Kumar, Raduan, \& Subramaniam, 2008; Lee \& Sukoco, 2010).

The degree of adaptation, the mode of adaptation and the facets of adjustment are decisive for the success of expatriation. Thus, intercultural adjustment occurs over a certain period of time, which presents a provision in the form of "U curve" (Araujo \& Nunes, 2012; Black et al., 1991; ChingHsiang \& Hung-Wen, 2008; Sousa, 2014). Back et al. (1991) have a set of stages for intercultural adjustment. These phases assume a U-shaped curve and emphasize the stages of adaptation to the new country (Figure 1).

Figure 1.: Theory of the U curve of intercultural adjustment.

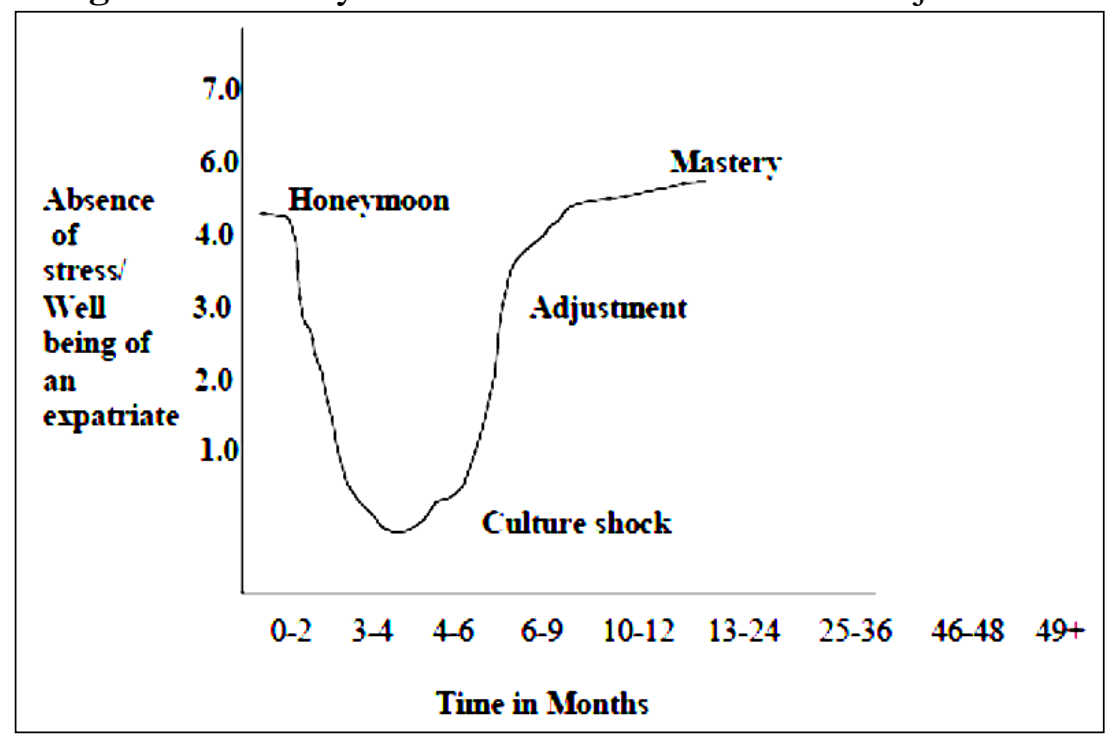

Source: Black et al. (1991).

According to the Theory of the "U Curve", intercultural adjustment can be characterized by four phases or stage: honeymoon, cultural shock 
and adaptation and control (Black et al., 1991). In the honeymoon phase, enchantment occurs and glimpse scans of the new country and culture, that is, feeling identical to that of a tourist. This period may range from 2 weeks to a few months (González \& Oliveira, 2011; Pereira et al., 2005; Sousa, 2014).

In the phase of cultural shock, disappointment occurs, the family begins to feel uncomfortable with daily life in the new country. At this stage, expatriates and families perceive differences in habits, triggering rejection reactions to the new culture. Feelings of loneliness, discomfort and disillusionment can cause anxiety, stress and premature return. This phase lasts, on average, from three to nine months (Black et al., 1991).

In the adaptation phase, family members feel comfortable and accept the new culture, understanding the behavior of the natives. At this stage, family members learn new behaviors and habits of the new culture. This phase occurs, on average, between the sixth and twelfth month (Black et al., 1991; Pereira et al., 2005). In the last phase, the control phase, the expatriate and his family start to like the culture and its daily routines, being able to live effectively in the new country. This phase usually occurs after the tenth month (Rego \& Cunha, 2009; Sousa, 2014).

In this process of intercultural adjustment, acculturation, especially in the cultural shock phase, is one of the determining factors for the success of the (Pereira et al., 2005). Acculturation can be interpreted as an understanding of culture, through the direct and continuous contact of groups and individuals from other cultures (Tertuliano, 2016).

According to Downes, Varner, \& Hemmasi (2010), the greater the individual's acculturation in relation to language, customs, attitudes and behaviors, the better the insertion of this individual into a new culture and, consequently, the greater the adaptation and success of the expatriate. However, changes in the formation of the "U curve" may occur due to situational and individual factors, affecting the adaptation pattern and generating oscillations in certain phases (Rego \& Cunha, 2009).

Based on the above, Pereira et al. (2005) propose four guidelines for the relations between cultural groups: (1) Integration - interest in the culture of the other group, but preserving the norms of culture itself; (2) Assimilation - interest in the culture of the other group, but not preserving the norms of culture itself; (3) Separation - preservation of the norms of culture itself, refusing the culture of the other group; (4) Marginalizationnot preservation of the norms of culture itself and refusal to culture of the other group.

In the sporting field, the change of environment, club, city, nation, language and culture is something that brings some discomfort, insecurity, and can generate the return of the athlete (repatriation) and psychological 
problems (Brandão, Magnani, Tega, \& Medina, 2013). The distance from home brings with it some consequences, such as lack of family, appetite and sleep disorders, depression, sadness, physical problems, stress elevation, mental exhaustion etc.

These causes are largely caused by the uncertainty of the new culture, and by an expectation influenced by anxiety and stress (Brandão et al., 2013). The family often suffers from the athlete, these consequences of expatriation, especially wives and children (Brandão et al., 2013).

The lack of preparation of the athlete, to leave the country is evident. According to the Brazilian Football Confederation (2016), in 2006, of the 851 players who went to foreign teams, 311 returned to Brazil in less than a year; in 2008, of the 1,176 players who went to foreign teams, 659 returned to Brazil in less than a year; and in 2010, of the 1,029 players who went to foreign teams, 683 returned to Brazil in less than a year, a figure of $66 \%$ of players who left the country. For Brandão et al. (2013), players who develop a better ability to adapt to new cultures stand out to others, enabling greater success in this process. Success in the expatriation process is important for player performance on the pitch.

Brandão et al. (2008) and Brandão \& Machado (2007) affirm that due to the context it is very difficult to transition to expatriates, because expatriation of athletes brings consequences not pleasant to him. In some cases, the expatriation process is related to family distance, loneliness, helplessness, new rules, fear, anguish, etc. (Brandão et al., 2013).

Within this scenario, the Intercultural adjustment model of Back et al. (1991) can be useful. According to the model, a good anticipatory adaptation facilitates the future adaptation to the new country. According to the model proposed by the authors, individual and organizational factors are responsible for anticipatory adaptation. The authors understand by anticipatory adaptation, the preparation training that is carried out before leaving for international migration, still in the country of origin.

Individual factors from the Back et al. (1991) model include three elements: (1) formation; (2) experience related to previous work; (3) Expectations. As for adapting to the new country of destination, the model presents four influencing categories: (1) individual factors; (2) workrelated factors; (3) organizational factors; (4) factors considered unrelated to work.

Individual factors are linked to the nature of the person and are facilitators, or not, adaptation to the new country. Thus, the more developed individual skills, the easier the adaptation will be. The work-related factors correspond to the possibility of the expatriate performing his role in the new country clearly. Organizational factors point to a greater degree of adaptation difficulty when there are possible differences between 
organizational cultures and the practices adopted by the company in the subsidiary. Finally, the factors not related to work point to the more pronounced the cultural differences between countries, the greater the difficulty of adaptation.

\section{INTERCULTURAL ADJUSTMENT IN THE SPORTING CONTEXT}

In the field of sport, there is a great transition of athletes between countries with different cultures (Faggiani et al., 2016; Tertuliano, 2016, 2018; Tertuliano, Machado, Oliveira, et al., 2018), however the preparation of athletes for this phenomenon is little worked, or rather, it is not worked (Agergaard, 2008; Agergaard \& Ryba, 2014; Brandão et al., 2013; Freitas, Costa Neto, Cardoso, \& Ferreira, 2012; Garrido, Olmos, Arjona, \& Pardo, 2012; Machado, 2013; Richardson, Littlewood, Nesti, \& Benstead, 2012; Sebben, 2009; Tertuliano, 2016; Tibbert, Andersen, \& Morris, 2015).

This non-preparation leads the athlete to an aculturation problem, that is, the athlete cannot adequately interpret the culture of the new club, leading the athlete to a wide set of emotional reactions, often unpleasant to the athlete (Faggiani et al., 2016; Pereira et al., 2005), like anxiety (Tibbert et al., 2015) and stress (Brandão et al., 2013), which characterizes the lack of intercultural adjustment.

In view of this, Tertuliano (2016) investigated the expatriation process in Volleyball. For this, the author aimed to investigate the factors that leads volleyball players to change countries, team and how it is their adaptation to the expatriation process. In this study, the author used athletes and former volleyball athletes, counting 68 participants, who answered a questionnaire developed according to the objectives of the study. The instrument consisted of structured questions with dichotomous answers (yes or no) or on a Likert scale. The results showed that the athletes, when they left their country of origin, had no difficulty in recognizing the culture of the new country.

Thus, the identity of the athletes was constructed in the face of identifications and differentiations, establishing psychological boundaries between personal and native limits (Machado \& Hernandes, 2004). Such identifications and differentiations can be given with the knowledge of new places, which may be related to the honeymoon phase, proposed by Black et al. (1991) in the theory of the "U curve" of intercultural adjustment. According to the theory, expatriate people, at the first moment, are enchanted by the novelties of the new country and its culture, wanting to know these newness and this culture.

Vol. 22, број 1/2020, стр. 63-78 
Regarding the cultural shock phase of theory, it seems that the athletes of the Tertullian study (2016) did not feel this phase in a position to hinder adaptation to the new country, because the results showed no discomfort or rejection of the new culture. This information can be interpreted from the following perspective: the athletes had integration with the new culture, but did not lose their own (Pereira et al., 2005). This means that the athletes assimilated the differentiations and, with this, knew how to separate their culture from native culture, which contributed to nondiscomfort in relation to living with the natives, refuting the results of other studies (Brandão et al., 2013; Freitas et al., 2012).

In relation to intercultural adjustment, it can be weaved that good coexistence with local culture is fundamental for the adaptation of the expatriate, because he feels received with hospitality and respect and, more than that, the assimilation and differentiation of cultures is relevant for the construction of mutual respect between the expatriate and the natives (Freitas et al., 2012), which can be interpreted as a necessary pillar for a good adaptation.

In the study by Tertuliano (2016) athletes demonstrated intercultural adjustment, that is, ability to adapt to the new cultural environment efficiently and sufficiently comfortably. However, this adaptation did not reduce the will of athletes returning to their country of origin. These attitudes demonstrate that athletes' family members can assist in the process of adaptation to expatriation, as the literature demonstrates (Brandão et al., 2013; Freitas et al., 2012; Machado, 2013; Rial, 2008).

According to Pereira et al. (2005), the success of expatriation has a direct relationship with the role of the family in the process of adaptation to expatriation, that is, the contact that the expatriate is expected to make with the new culture is not only a superficial contact and without insertion of the expatriate in the new culture. Thus, it is expected that the expatriate is an active agent, whose resources for action originate from his culture and that the family is one of the fundamental forces for this insertion in the new culture and exchange between cultures.

Thus, the construction of the expatriate's space of coexistence with the new culture is strengthened by the constant and remarkable presence of the elements of their origin culture, which in this case is presented by the family, which is necessary. Some studies on expatriation reinforce the argument about the importance of the family (Dowling, Festing, \& Engle, 2008; Pereira et al., 2005). These studies show that the acceptance of tasks in other locations, without the transfer of family members reduces the number of adherents to the expatriation process.

Expatriates without family suffer from cultural shock more strongly than expatriates who are accompanied by their family's (Dowling et al., 
2008). In addition, these studies show that living with the natives is facilitated when there is the support of the family and that the dedication at work is greater, thus with career success. Within this perception, sending the family to the expatriate now has a fundamental role, not only in the adaptation of the same, but in the success of the task to which the expatriate was appointed (Pereira et al., 2005).

According to Sousa (2014), the family is a way for expatriates to obtain emotional stability and support in the face of new situations that may occur in the expatriation process, and can reduce adaptation problems such as anxiety, fear, loneliness, etc. There is a willingness on the part of the expatriate family to discover new cultures, new customs and new habits, which contributes to the adaptation of the expatriate in the face of socialization and intercultural adjustment.

However, this desire is common in the period of "honeymoon" of the family and the expatriate himself. The problem of the family with the expatriate is that the impacts of the cultural shock are transferred to the expatriate's family, which can generate, in this case, a cultural shock in the family. Thus, one should think with caution this process of expatriation of the family because, in this case, the athlete will be hours a day without contact with the local culture, since he will be in training at the club, which will not occur with the family. In other words, the family should be inserted into the expatriation process, but the training of the same is necessary, so that everyone, athlete and family, can adapt adequately to the expatriation process.

Often the family comes across the interruption of their personal lives, in relation to their lives with friends and daily routine (Tertuliano, Oliveira, Pavlović, et al., 2018; Tertuliano, 2016), besides having little help administering daily demands in circumstances outside the family environment to which they were used to. A possible solution to this cultural shock of the family is the training and support for the athlete's family members, since the permanence of the family contributes to the success of the expatriation process.

In this sense, some work, in order to minimize the impacts and facilitate the cultural adjustment of the expatriate and his family, are carried out by the companies (Pereira et al., 2005; Shaffer, Ferzandi, Harrison, Gregersen, \& Black, 2006). These programs are based on two perspectives: (a) Work-related factors, so that the expatriate is included in the new work, setting it with the new function, degree of involvement, technical and resource limitations, local legislation, expatriation objectives, etc.; (b) Factors related to organizational culture and outside work, in order to support expatriates and their families, such as housing, school, instructions 
on local services (supermarket, cinema, hospitals, etc.), instructions that help reduce distance between cultures, etc.

In addition to all this, the role of the family is of paramount importance for the success and permanence of the expatriate in the new country. Thus, Pereira et al. (2005) suggest that the expatriation process should be accompanied by training to facilitate intercultural adjustment. The authors suggest that the expatriation process should occur, respecting some criteria for its success: (a) inclusion, in the selection of expatriate candidates, of the cultural profile of the candidate's family; (b) have preference for candidates in which the family has already had contact with another culture; (c) creation of pre-expatriation programs with the inclusion of language communication training in the host country; (d) continuity of the program upon arriving in the country of destination.

Finally, it can be said that within the process of expatriation and better interculturality, intercultural psychology plays an important role, because it adds values to the athlete, values that are fundamental to emotional balance and, consequently, better adaptation to the new context. Thus, there is the eminent need for intercultural adjustment programs against expatriates, especially in the sporting context. In addition, for the success of the programs, some authors suggest that the content covered contains the rules of decorum or courtesy to be respected by the expatriate (Pereira et al., 2005), as mentioned above.

\section{FINAL CONSIDERATIONS}

Although globalization has made expatriation, whether in the sporting context or outside it, become increasingly common, this is not always an easy or natural process. Therefore, it is important to better understand some factors that seem to be inherent to the expatriation process, such as family longing, fear of change and other psychological factors (Brandão et al., 2013; Pontes, Ribeiro, Garcia, \& Pereira, 2018; Tertuliano, 2016; Tertuliano, Oliveira, et al., 2019), because such factors may compromise the adaptation of the expatriate to the new environment and, consequently, compromise intercultural adjustment (Agergaard \& Ryba, 2014; Brandão et al., 2013; Faggiani, 2017; Pontes et al., 2018; Tertuliano, Oliveira, Pavlović, et al., 2018).

In the sports context, studies indicate that some of the athletes return before their first year abroad (Brandão et al., 2013; Faggiani, 2017; Faggiani et al., 2016; Richardson, Cowan, Callaghan, \& Kan, 2016; Tertuliano, 2016; Tertuliano, Machado, Deustch, et al., 2018), thus showing that they do not reach the last phase of the model proposed by Black et al. (1991) and revealing existing flaws in the process of cultural 
adjustment. In addition, it is important to understand that during the process, a set of emotions can hinder the athlete's performance, causing their income to decline, which can be a big problem at the same while performing and maintaining at the club.

In addition, the training routine changes (Tertuliano, 2016; Tertuliano, Machado, Oliveira, et al., 2018; Tibbert et al., 2015), the distance from the family (Richardson et al., 2016; Tertuliano, Oliveira, Pavlović, et al., 2018; Weedon, 2011), the difficulty of the language of the new country (Richardson et al., 2012; Tertuliano, 2016; Weedon, 2011) and cultural shock (Agergaard, 2008; Agergaard \& Ryba, 2014; Faggiani et al., 2016; Richardson et al., 2012; Tertuliano, Oliveira, et al., 2019; Weedon, 2011) may negatively influence the expatriation process of athletes, demonstrating that this process requires monitoring and guidance (Faggiani et al., 2016). In addition to the human factor, which is undoubtedly important, it is relevant to note that companies or clubs do not rarely invest fortunes in the transfer of the athlete or employees, and therefore care is necessary for the performance of this to be in accordance with what is expected.

The family also plays a key role in the success or failure of the cultural adjustment of an athlete or employee leaving their country (Santos, 2011). In addition to its direct influence on the expatriate, it must be considered that the family of this, who in turn abandons employment, friends, social life and other activities to follow him, also suffers those with the same difficulties, and therefore needs attention (Rodrigues, 2010).

In this sense, future studies could be paid to deepening such aspects and their interrelationships in order to enable analyses about these factors in order to be able to propose interventions and follow-ups to control such factors, in order to promote adequate intercultural adjustment.

\section{REFERENCES}

1. Agergaard, S. (2008). Elite athletes as migrants in Danish women's handball. International Review for the Sociology of Sport, 43(1), 519. https://doi.org/10.1177/1012690208093471

2. Agergaard, S., \& Ryba, T. V. (2014). Migration and Career Transitions in Professional Sports: Transnational Athletic Careers in a Psychological and Sociological Perspective. Sociology of Sport Journal, 31(2), 228-247. https://doi.org/10.1123/ssj.2013-0031

3. Andreff, W. (2010). Why Tax International Athlete Migration? The 'Coubertobin' Tax in a Context of Financial Crisis. In J. Maguire $\&$ M. Falcous (Eds.), Handbook on Sport and Migration: Borders, Boundaries and Crossings (pp. 31-45). Oxon: Routledge. 
4. Angelini, A. L. (2007). Psicologia Intercultural e Psicologia Educacional - Uma contribuição histórica. Boletim Academia Paulista de Psicologia, 27(2), 39-46.

5. Araujo, B. F. V. B., \& Nunes, I. M. (2012). Inteligência Cultural, Adaptação Transcultural e Desempenho de Expatriados: um estudo por meio de Equações Estruturais. In XXXVI Encontro do ANPAD (pp. 1-16). Rio de Janeiro: ANPAD.

6. Black, S. J., Mendenhall, M., \& Oddou, G. (1991). Toward a Comprehensive Model of International Adjustment: an Integration of Multiple Theoretical Perspectives. The Academy of Management Review, 16(2), 291-317. https://doi.org/10.5465/amr.1991.4278938

7. Brandão, M. R. F., \& Machado, A. A. (2007). Teoria e Aplicação: Coleção Psicologia do esporte e do exercício (1st ed.). São Paulo: Atheneu.

8. Brandão, M. R. F., Machado, A. A., Medina, J. P., \& Scaglia, A. J. (2008). Futebol, psicologia e a produção do conhecimento: Coleção Psicologia do esporte e do exercício. (4th ed.). São Paulo: Atheneu.

9. Brandão, M. R. F., Magnani, A., Tega, E., \& Medina, J. P. (2013). Além da cultura nacional: o expatriado no futebol. Revista Brasileira de Ciência e Movimento, 21(2), 177-182. https://doi.org/10.18511/rbcm.v21i2.4143

10. Ching-Hsiang, L., \& Hung-Wen, L. (2008). Cross-Cultural Adjustment of Expatriates: Theory \& Research Findings on American and Japanese Expatriates. Cross Cultural Management, 15(2), 176-193.

11. Confederação Brasileira de Futebol. (2016). Transferências internacionais: números de 2015. Retrieved May 17, 2018, from https://www.cbf.com.br/a-cbf/informes/index/transferenciasinternacionais-numeros-de-2015

12. Dowling, P. J., Festing, M., \& Engle, A. D. (2008). International human resource management: Managing people in a multinational context (5th ed.). Cengage Learning.

13. Downes, M., Varner, I., \& Hemmasi, M. (2010). Individual profiles as predictors of expatriate effectiveness. Competitiveness Review, 20(3), 235-247. https://doi.org/10.1108/10595421011047424

14. Earley, C., \& Ang, S. (2003). Cultural intelligence: Individual interactions across cultures. Stanford: Stanford Business Books.

15. Faggiani, F. T. (2017). O processo de aculturação e a adultez emergente em atletas de Futebol. (Doctoral thesis). Pontífica Universidade Católica do Rio Grande do Sul, Porto Alegre, Brazil. 
16. Faggiani, F. T., Strey, A., Fuginiti, D., Lindern, D., Aiquel, P. F., \& Sartori, C. (2016). O Fenômeno do Expatriado no Contexto Esportivo. Psicologia: Ciência e Profissão, 36(3), 738-747. https://doi.org/10.1590/1982-3703001832016

17. Freitas, L. P. R., Costa Neto, J. R., Cardoso, R. M., \& Ferreira, M. P. P. (2012). Estudo do fenômeno do regresso de ex-atletas sulmineiros de futebol do exterior. Lecturas: Educación Física y Deportes, 16(164), 1-9. Retrieved from https://www.efdeportes.com/efd164/regresso-de-sul-mineiros-defutebol-do-exterior.htm

18. Garrido, A. A., Olmos, J. C. C., Arjona, N. G., \& Pardo, R. (2012). Immigration, school, physical activity and sport. Analysis of sport acculturation in Spain. Kinesiology, 44(1), 83-93. Retrieved from https://www.researchgate.net/publication/283112984_Immigration _school_physical_activity_and_sport_analysis_of_sport_accultura tion_in_Spain

19. González, J. M. R., \& Oliveira, J. A. (2011). Os efeitos da expatriação sobre a identidade: estudo de caso. Cadernos EBAPE.BR, 9(4), 1122-1135. https://doi.org/10.1590/S167939512011000400011

20. Kumar, N., Raduan, C. R., \& Subramaniam. (2008). The Effects of Personality and Cultural Intelligence on International Assignment Effectiveness: A Review. Journal of Social Sciences, 4(4), 320328. https://doi.org/10.3844/jssp.2008.320.328

21. Lee, L., \& Sukoco, B. M. (2010). The effects of cultural intelligence on expatriate performance: moderating effects of international experience. The International Journal of Human Resource Management, 21(7), 963-981. https://doi.org/10.1080/09585191003783397

22. Lee, L., \& Vorst, D. V. (2010). The influences of social capital and social support on expatriates' cultural adjustment: an empirical validation in Taiwan. International Journal of Management, 27(3), 628-650.

23. Machado, F. S. (2013). Gestão de pessoas interncional no contexto esportivo brasileiro: uma análise dos processos de expatriação e repatriação de jogadores em um clube de futebol gaúcho. (Masters dissertation). Universidade Federal do Rio Grande do Sul, Porto Alegre. Brazil.

24. Machado, H. V., \& Hernandes, C. A. (2004). Alteridade, Expatriação e Trabalho: Implicações para a Gestão Organizacional. Revista de Administração Contemporânea, 8(3), 53-73. https://doi.org/10.1590/S1415-65552004000300004 
25. Marconi, M. A., \& Lakatos, E. M. (2017). Metodologia Cientifica (7th ed.). São Paulo: Atlas.

26. Martins, D. (2011). Gestão e Retenção de Repatriados: Um Estudo empírico em empresas portuguesas. (Doctoral thesis). Faculdade de Economia do Porto, Porto, Portugal.

27. Pereira, N. A. F., Pimentel, R., \& Kato, H. T. (2005). Expatriação e estratégia internacional: o papel da família como fator de equilíbrio na adaptação do expatriado. Revista de Administração Contemporânea, 9(4), 53-71. https://doi.org/10.1590/S141565552005000400004

28. Pontes, V. S., Ribeiro, C. H. V., Garcia, R. M., \& Pereira, E. G. B. (2018). Migração no Voleibol brasileiro: a perspectiva de atletas e treinadores de alto rendimento. Movimento, 24(1), 187-198. https://doi.org/10.22456/1982-8918.66495

29. Rego, A., \& Cunha, M. P. (2009). Manual de Gestão Transcultural de Recursos Humanos. Lisboa: RH Editora.

30. Rial, C. (2008). Rodar: a circulação dos jogadores de futebol brasileiros no exterior. Horizontes Antropológicos, 14(30), 21-65. https://doi.org/10.1590/S0104-71832008000200002

31. Richardson, D., Littlewood, M., Nesti, M., \& Benstead, L. (2012). An examination of the migratory transition of elite young European soccer players to the english premier league. Journal of Sport Sciences, $30(15), \quad 1605-1618$. https://doi.org/10.1080/02640414.2012.733017

32. Richardson, R., Cowan, C. S., Callaghan, B. L., \& Kan, J. M. (2016). Effects of early-life stress on fear memory in the developing rat. Current Opinion in Behavioral Sciences, 7, 15-20. https://doi.org/10.1016/j.cobeha.2015.10.003

33. Rodrigues, F. X. F. (2010). O fim do passe e as transferências de jogadores Brasileiros em uma época de globalização. Sociologias, 12(24), 338-380. $\quad$ https://doi.org/10.1590/S151745222010000200012

34. Santos, G. G. (2011). Desenvolvimento de Carreira: Uma análise centrada na relação entre o trabalho e a família. Lisboa: Editora RH.

35. Sebben, A. (2009). O preparo do atleta de futebol. Retrieved May $17, \quad 2015$, from http://universidadedofutebol.com.br/andreasebben-psicologa-parte-1/

36. Shaffer, M. A., Ferzandi, L. A., Harrison, D. A., Gregersen, H., \& Black, J. S. (2006). You can take it with you: individual differences and expatriate effectiveness. Journal of Applied Psychology, 91(1), 1-35. https://doi.org/10.1017/CBO9781107415324.004 
37. Sousa, A. F. B. (2014). A adaptação intercultural da família: um estudo exploratório com expatriados portugueses. (Masters dissertation). Instituto Politécnico do Porto, Vila do Conde, Portugal.

38. Tertuliano, I. W., Oliveira, V., Pavlović, V., \& Machado, A. A. (2018). The need for expatriation and the planning of the process: Organizational looks for sports. Ekonomski Pogledi, 20(1), 1-17.

39. Tertuliano, I. W. (2016). Processo de expatriação de voleibolistas: Concepções Bioecológicas. (Doctoral thesis). Universidade Estadual Paulista, Rio Claro, Brazil.

40. Tertuliano, I. W. (2018). Expatriados e atletas nômades. In F. Rebustini \& A. A. Machado (Eds.), Vulnerabilidade no Esporte: Volume 2 (1st ed., pp. 57-74). Jundiaí: Paco.

41. Tertuliano, I. W., Machado, A. A., Deustch, S., Montiel, J. M., \& Bartholomeu, D. (2018). Motivos e intenções para expatriação de voleibolistas. Revista de Administração Contemporânea, 22(4), 531-551. https://doi.org/10.1590/1982-7849rac2018170032

42. Tertuliano, I. W., Machado, A. A., Oliveira, V., Montiel, J. M., Bartholomeu, D., \& Deutch, S. (2018). Athletic expatriation and volleyball: adaptation to the new club. Manual Therapy, Posturology \& Rehabilitation Journal, 16(626), 1-8. https://doi.org/10.17784/mtprehabjournal.2018.16.626

43. Tertuliano, I. W., Montiel, J. M., Deutsch, S., \& Machado, A. A. (2019). Considerações em relação a expatriação e Globalização: Interfaces com aspectos emocionais. Revista Inteligência Competitiva, 9(1), 15-30. https://doi.org/10.24883/ric.v9i1.300

44. Tertuliano, I. W., Oliveira, V., \& Santana, B. A. (2019). Expatriates and international carrer management: corporate and sporting context. Economic Outlook, 21(2), 1-17. Retrieved from https://scindeks-clanci.ceon.rs/data/pdf/1450-7951/2019/145079511902001W.pdf

45. Tibbert, S. J., Andersen, M. B., \& Morris, T. (2015). What a difference a "Mentally Toughening" year makes: The acculturation of a rookie. Psychology of Sport and Exercise, 17, 68-78. https://doi.org/10.1016/j.psychsport.2014.10.007

46. Tucker, M. F., Bonial, R., \& Lahti, K. (2004). The definition, measurement and prediction of intercultural adjustment and job performance among corporate expatriates. International Journal of Intercultural Relations, 28(3-4), 221-251. https://doi.org/10.1016/j.ijintrel.2004.06.004

47. Tylor, E. B. (1920). Primitive culture: researches into the development of mythology, philosophy, religion, language, art, and 
custom (6th ed.). London: John Murray.

48. Weedon, G. (2011). "Glocal boys": exploring experiences of acculturation amongst migrant youth footballers in premier league academies. International Review for the Sociology of Sport, 47(2), 200-216. https://doi.org/10.1177/1012690211399221

Рад је примљен: 05.10.2019.

Рад је прихваћен за штампу: 13.11.2019. 